Egyptian Journal of Aquatic Biology \& Fisheries

Zoology Department, Faculty of Science,

Ain Shams University, Cairo, Egypt.

ISSN $1110-6131$

Vol. 22(5): 473 - 482 (2018)

www.ejabf.journals.ekb.eg

\title{
Alpheus lobidens De Haan, 1849 (Decapoda, Alpheidae) as a new record to the Egyptian Mediterranean Coast
}

\author{
Rasha Hamdy and Mohamed Dorgham \\ Oceanography Department, Faculty of Science, Alexandria University, Egypt \\ Corresponding author: mdorgham1947@yahoo.com
}

\section{ARTICLE INFO \\ Article History: \\ Received: Nov. 24, 2018 \\ Accepted: Dec. 29, 2018 \\ Online: Jan. 2019}

Keywords:

Alpheus lobidens

Snapping shrimp

Egyptian Mediterranean

Alexandria

Eastern Harbour

\section{ABSTRACT}

Alpheus lobidens is one of the widely distributed snapping shrimps at different depths (up to $25 \mathrm{~m}$ ) on soft and hard bottoms of the warm coastal habitats. It has received great attention because it was previously misidentified and described as Alpheus crassimanus. The present study recorded A. lobidens for the first time in the Eastern Harbour of Alexandria on the Egyptian Mediterranean Coast in association with a recently described bryozoan species, Calyptotheca alexandriensis. The seasonal abundance, biometric parameters and the females' fecundity of A. lobidens in the Eastern Harbour were followed during the present study. A total of 76 individuals were collected, with the highest count during spring and the lowest in autumn. The biometric measurements showed that A. lobidens had lengths within the range of $9-32 \mathrm{~mm}$ and weight of $3-691 \mathrm{mg}$, for different maturity stages. In the meantime, Ovigerous females formed the highest percent of the population count during summer.

\section{INTRODUCTION}

Snapping shrimps of the genus Alpheus Fabricius, 1798 were found to inhabit soft and hard bottoms in estuaries, mangroves and coral reefs within variable depths in coastal tropical and subtropical regions (Anker et al. 2006). Some Alpheus species were associated with different types of benthic animals (e.g. Anker et al. 2008; Purohit et al. 2014). For Example, Alpheus ikedosoma was found in association with the annelid echiurian Ikedosoma elegans in the intertidal sandy zone of Boso Peninsula and Ariake Sea, Japan (Komai, 2015).

Alpheus lobidens is one of the widely distributed snapping shrimps in the world coasts and received great attention, as it was misidentified and described as $A$. crassimanus in several coastal areas, including Mediterranean coasts (Forest and Guinot, 1958; Holthuis and Gottlieb, 1958), and many areas in the Indo-Pacific (Bannr and Banner, 1974).

Alpheus lobidens was observed in the entire Indo-Pacific area from the Red Sea to Hawaii, from all warmer parts of Australian coast (e.g. Almeida et al. 2013; Purohit et al. 2014; Tan et al. 2017), the ROPME Sea Area (Naderloo and Türkay, 2012; Jahanpanah and Savari, 2013; Akbarian et al. 2014), intertidal zones of Oman Sea (Naderloo et al. 2015; Ansari and Maghsoodlou, 2017) and Juraid Island, Saudi Arabia (Banner and Banner, 1981). 
Although A. lobidens was mentioned in the list of Red Sea species to Mediterranean Sea (Rodríguez and Suárez, 2001), it was reported as rare species from Israeli coast (Lewinsohn and Galil, 1982) and in Turkish Mediterranean waters (Kocatas et al. 2002; Bakir et al. 2015). However, it was not included in the lists of alien species in the Mediterranean (Galil, 2007; Abushaala et al. 2014; Ben Amor et al. 2016; Zenetos, 2017). This species could be considered as new record to the Egyptian Mediterranean coast as it was found for the first time among the fauna associated with a newly discovered bryozoan species, Calyptotheca alexandriensis in the Eastern Harbour of Alexandria by Abdel Salam et al. (2017).

The present study aims at following the seasonal variations of abundance, biometric parameters and fecundity of A. lobidens in the Eastern Harbour of Alexandria, Egypt.

\section{MATERIALS AND METHODS}

\section{Study area}

The Eastern Harbour of Alexandria has an international concern due to its historical importance, as a reservoir for thousands of ancient Egyptian artifacts. Regardless of being small shallow semi-closed basin on the southeastern Mediterranean coast (Fig.1) the Eastern Harbour represents one of the coastal areas of changeable environmental conditions.
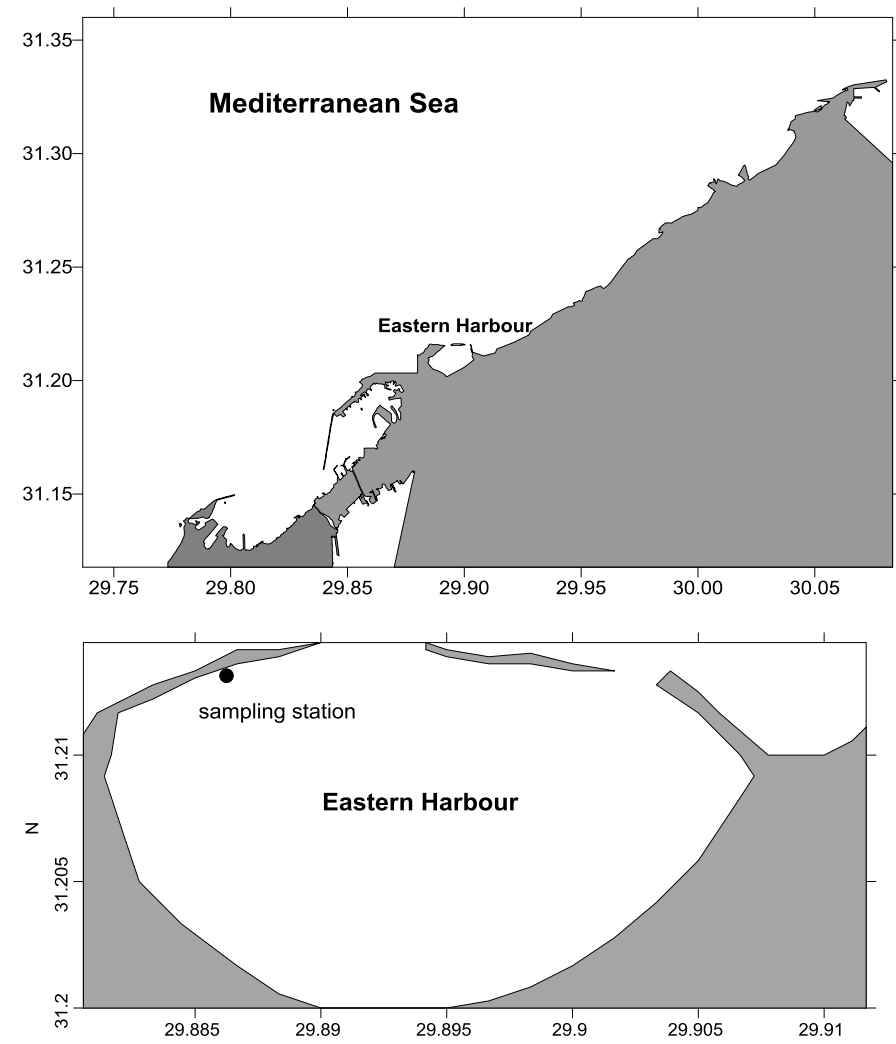

Fig. 1: The Eastern Harbour of Alexandria, inclưding position of the sampling station.

These conditions are associated with fundamental changes during the past seven decades, including cessation of the Nile flood, modification of the sewer system of the Alexandria City, and variations in human activities. Other factors also impact the ecological characteristics of the Eastern Harbour, like the rapid water exchange with the sea during a flushing time of 1.3 - 2.9 days (El Bessa, 2011), 
seasonal current regime (Abdalla, 1979; El-Geziry and Maiyza, 2006), and remobilization of nutrients from sediments to the water column (Awad, 2004).

\section{Samples collection}

During the year 2018 bryozoan $C$. alexandriensis colonies were collected in three replicates during winter, spring, summer, and autumn, from rocky substrate at a depth of $1.0-1.5 \mathrm{~m}$ in the Eastern Harbour of Alexandria (Fig. 1). The bryozoan shells were gently crushed in the laboratory and shrimp specimens were carefully collected, and preserved in $10 \%$ formalin.

Biometric parameters were measured for all the collected shrimps (76 specimens), including the total length (TL), total weight (TW), carapace length (CL: distance between tip of rostrum to the posterior margin of the carapace). The fecundity was determined by counting of all embryos of different developmental stages in the ovigerous females.

The relationships between the biometric parameters were assessed by using regression and Pearson moment correlation analysis. The length-weight relationship was determined according to the equation $\mathrm{W}=\mathrm{aL}^{\mathrm{b}}$ (Hile 1936; Beckman 1948), where "W" is the total body wet weight (mg), "L" the body length (mm), "a" constant and "b" is the growth coefficient.

\section{RESULTS}

The physical chemical parameters in the study area are given in Table (1). The surface water temperature fluctuated between a minimum of $15.1{ }^{\circ} \mathrm{C}$ in winter and a maximum of $29^{\circ} \mathrm{C}$ in summer. Salinity sustained value between $33.9 \%$ and 36.5 $\%$, that is mostly lower than the salinity of the offshore waters in the Egyptian Mediterranean Coast (usually $>38 \%$ ). This is mainly due to the direct and indirect effect of anthropogenic discharges from the adjacent lands. The $\mathrm{pH}$ was comparatively higher than that usually found in other areas and strongly correlated $(\mathrm{r}=0.67-0.81$ in different seasons at $\mathrm{p}=0.05)$ with the dissolved oxygen, that sustained high concentrations between $4.0 \mathrm{mg} / \mathrm{l}$ and $18.3 \mathrm{mg} / \mathrm{l}$. The area was characterized by high nutrients accompanied by high phytoplankton biomass (Table $1)$.

Table 1: Variation ranges of physical chemical parameters in the area around the bryozoans during the sampling months (Shaban et al. personal communication, 2016).

\begin{tabular}{|l|l|l|l|l|l|}
\hline \multicolumn{1}{|c|}{ Feb. } & \multicolumn{1}{c|}{ Apr. } & \multicolumn{1}{c|}{ Jun. } & \multicolumn{1}{c|}{ Aug. } & \multicolumn{1}{c|}{ Oct. } \\
\hline Temp. & $15.1-18.1$ & $18.5-23.5$ & $25-29$ & $29-31.5$ & $24.5-27.5$ \\
\hline Salinity & $33.9-36.1$ & $33.7-36.1$ & $33.9-36.2$ & $34.1-36.1$ & $34.2-36.5$ \\
\hline $\mathrm{pH}$ & $7.85-8.28$ & $7.94-8.4$ & $7.92-8.71$ & $7.89-8.49$ & $8.04-8.72$ \\
\hline $\mathrm{DO}$ & $7.9-14.3$ & $6.5-18.3$ & $6-17$ & $4.35-14.58$ & $4.0-16.2$ \\
\hline $\mathrm{NO}_{2}-\mathrm{N}$ & $0.5-14.2$ & $0.3-3.2$ & $0.35-1.57$ & $0.46-1.73$ & $0.24-2.55$ \\
\hline $\mathrm{NO}_{3}-\mathrm{N}$ & $7.99-57.95$ & $6-19.57$ & $1.5-15.54$ & $6.62-18.6$ & $1.23-42.05$ \\
\hline $\mathrm{PO}_{4}-\mathrm{P}$ & $0.77-11.5$ & $0.01-1.7$ & $0.15-1.33$ & $0-2.2$ & $0.01-0.78$ \\
\hline $\mathrm{N} / \mathrm{P}$ & $1.3-55.5$ & $5.5-600.2$ & $1.6-71$ & $5.8-271.4$ & $3.4-354.9$ \\
\hline $\mathrm{SiO} 4-\mathrm{Si}$ & $0.01-14.8$ & $0.4-8.7$ & $0.8-4.9$ & $0.8-12.1$ & $0.6-9.1$ \\
\hline $\mathrm{Chl} a$ & $0.83-6.9$ & $0.65-6.68$ & $0.68-1.36$ & $3.24-22.41$ & $0.9-2.84$ \\
\hline
\end{tabular}

A total of 76 specimens of $A$. lobidens were collected during the present study, including 22 in winter, 43 in spring, 10 in summer (June and August), and one in autumn. As shown in Figure 2, the collected individuals had a total length between 9 and $32 \mathrm{~mm}$, with the dominance $(66.2 \%)$ of individuals with lengths between $10-20$ 
$\mathrm{mm}$. Meanwhile, the shorter $(<10 \mathrm{~mm})$ and longer individuals $(>30 \mathrm{~mm})$ showed pronouncedly low contribution to the total population (Fig. 2). The seasonal pattern of length distribution indicated the prevalence of the length group 15-20 mm during winter and spring (Fig. 3 a, b), while the summer population was dominated by longer individuals, including $50 \%$ with length $>25-30 \mathrm{~mm}$ and $30 \%$ with length between $>20-25 \mathrm{~mm}$ (Fig. 3c). The autumn specimen had similar lengths of the summer individuals $(30 \mathrm{~mm})$.

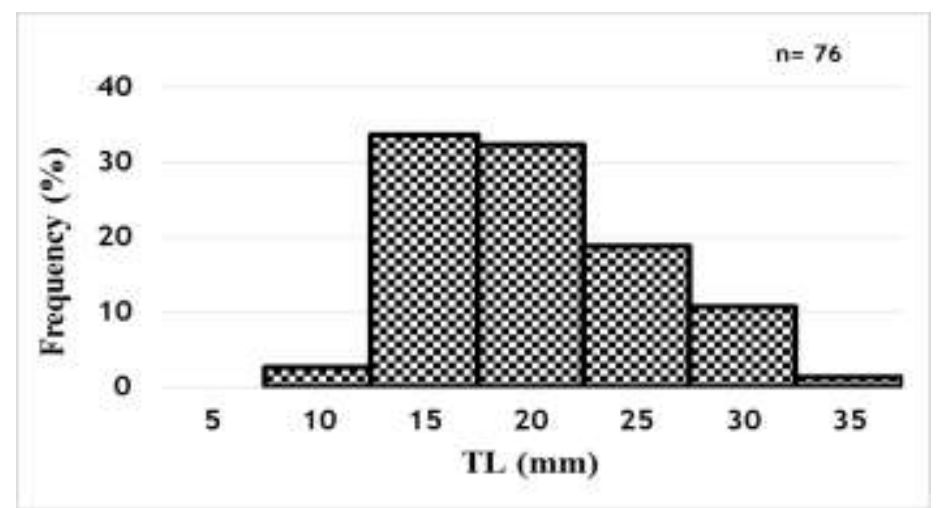

Fig. 2: Length frequency of Alpheus lobidens over the year.
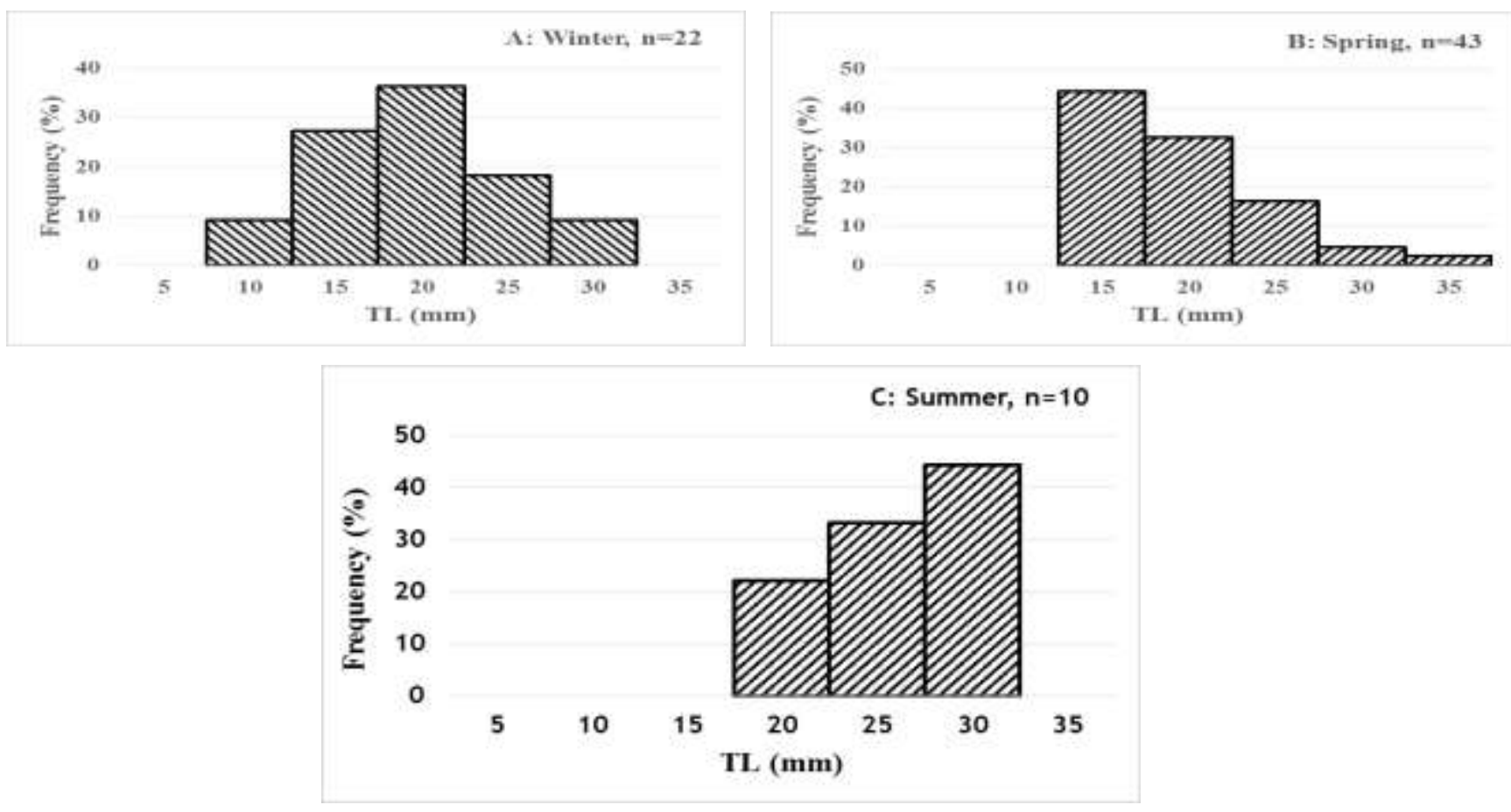

Fig. 3 Length frequency of Alpheus lobidens (n: number of specimens measured) in diferent seasons.

It is worth to mention that several specimen were weighed without one or both claws, because they were lost during the samples collection. The wet weight of shrimps without claws varied between 3 and $691 \mathrm{mg}$, and the majority of individuals (53\%) displayed weight $<100 \mathrm{mg}$, against $16 \%$ with $100-<200 \mathrm{mg}$ and $12 \%$ with 200 $300 \mathrm{mg}$ (Fig. 4). The winter individuals without claws had weight between 18 and 
$418 \mathrm{mg}$, spring individuals between 25 and $691 \mathrm{mg}$ and those of summer between $151-730 \mathrm{mg}$, while the single specimen of autumn weighed $715 \mathrm{mg}$.

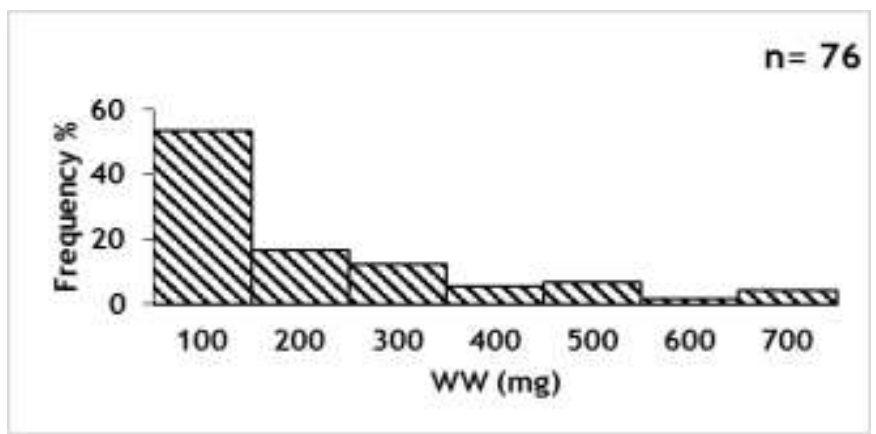

Fig. 4: Weight frequency of Alpheus lobidens over the year.

Based on the length and weight of individuals with the two chelipeds the formula of length-weight relationship for A. lobidens was calculated to be $\mathrm{W}=$ $0.0175 \mathrm{TL}^{3.1899}(\mathrm{r}=0.885, \mathrm{SE}=0.06)$ (Fig. 5a), but when use carapace length with total weight the formula was $\mathrm{W}=0.2828 \mathrm{CL}^{3.4966}(\mathrm{r}=0.877$, $\mathrm{SE}=0.02)$ (Fig. 5b). Both equations revealed that the growth coefficient (b) was $>3$, indicating positive allometric growth. The regression relationship between the TL and the CL demonstrated a strong significant linear relationship at $r=0.966$ (Fig. 6).

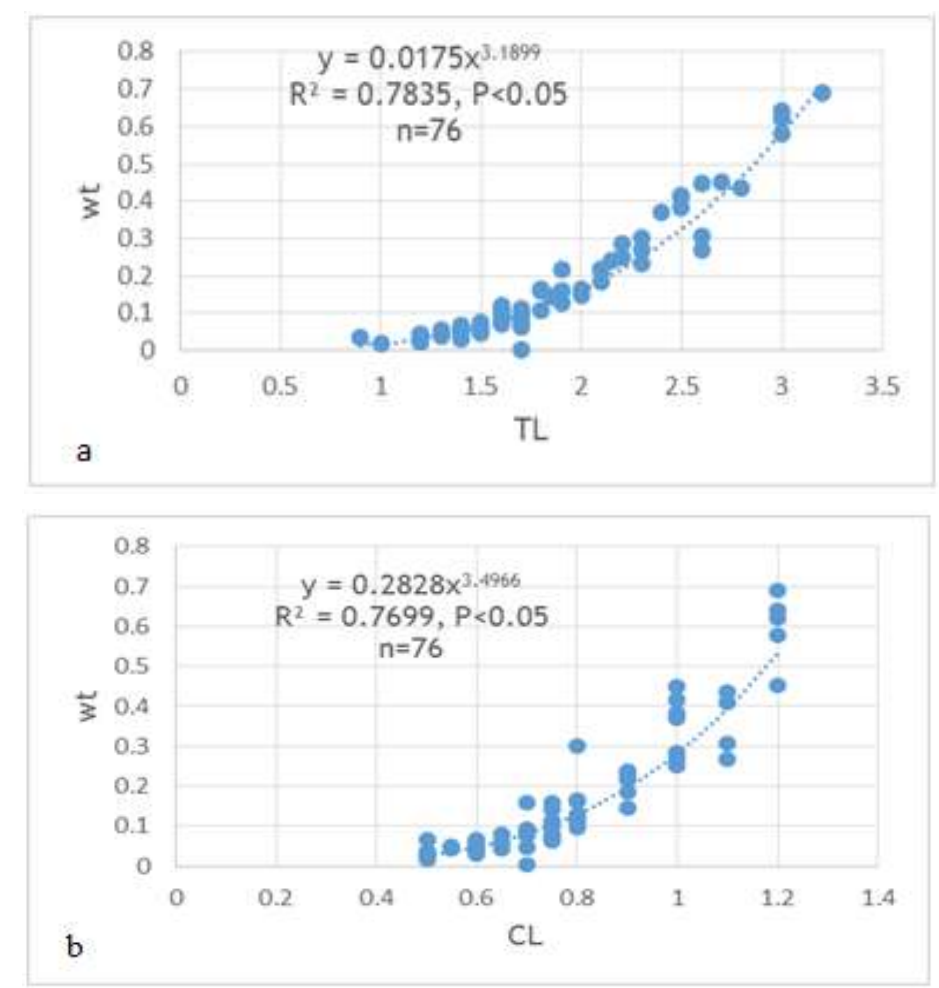

Fig. 5: Length-weight relationship of Alpheus lobidens; a: with total length (TL), b: with carapace length (CL). 


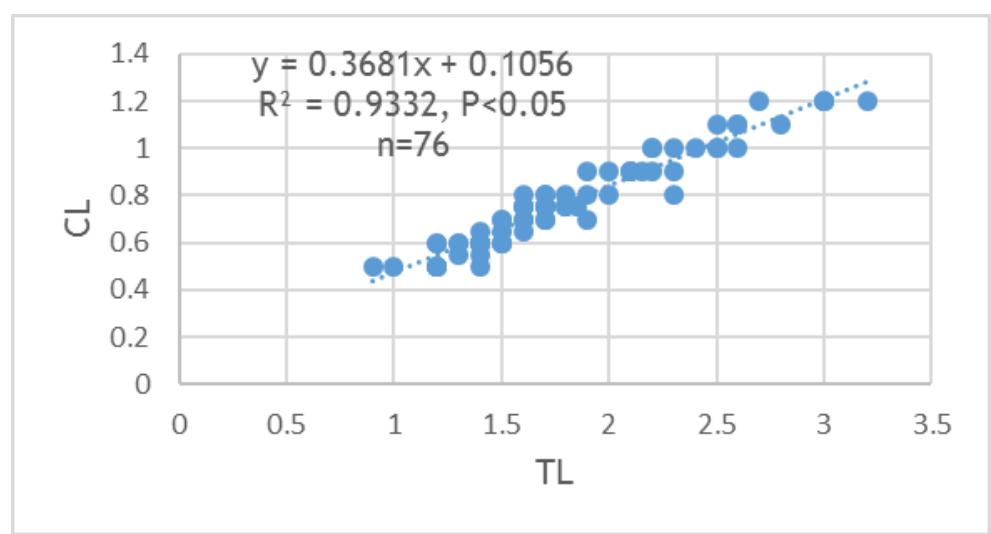

Fig. 6. Relationship between total length (TL) and carapace length (CL).

Of the total number of collected shrimp (76) during the present study, only 13 ovigerous females were observed with TL of $18-32 \mathrm{~mm}$ and CL of $8-12 \mathrm{~mm}$. The fecundity of these females was estimated at 3 different embryonic developmental stages. The first stage included females carrying spherical eggs and had length range of 20-22 mm without clear embryos, these females showed a fecundity of $273 \pm 102$ egg/female. The second stage was represented by females with TL of $23 \mathrm{~mm}$ and CL of $9 \mathrm{~mm}$, carrying ellipsoidal eggs with young embryos and their fecundity was 302 embryos/female. The third stage comprised females with TL of 30-32 $\mathrm{mm}$ and carried ellipsoidal eggs with embryos near hatching, these females recorded fecundity of $563 \pm 112$ embryos/female.

\section{DISCUSSION}

Alpheus lobidens exhibited ability to exist in the intertidal zone and deeper to about $25 \mathrm{~m}$ (Banner and Banner, 1982) in widely different substrates, like carbonate sand horizontal tunnel (Farrow, 1971), jumble of boulders shores, small stones, loose bedrock, coarse sand, dead coral reef and oil polluted muddy sediment (Hosseini, 2009). In the Eastern Harbour of Alexandria, A. lobidens was found in association with the calcareous shells of the bryozoan $C$. alexandriensis on hard shallow bottom at depth range of $1-1.5 \mathrm{~m}$.

The world wide geographic distribution of A. lobidens indicates its ability to exist under different ecological conditions, like temperature, salinity, water movement, food availability and others. However, its numerical abundance appeared to be largely affected by these conditions as indicated from the great differences in the abundance of this species among the studied world regions (Table 2). During the present study, A. lobidens occurred at comparatively low salinity $(33.7-36.5 \%$ ), relatively wide $\mathrm{pH}$ range (7.85- 8.71), and high phytoplankton biomass (chl $a$ : up to $6.9 \mu \mathrm{g} / \mathrm{l})$. Despite the high fertility of the Eastern Harbour as favourable habitat for $A$. lobidens it hosted pronouncedly low count of this shrimp as compared to other world areas (Table 2). This may be explained by the rapid change in the environmental conditions due to the short flushing time, the effect of anthropogenic discharges, and the strong wave action on the sampling site. 
Table 2: The individual count of Alpheus lobidens in different coastal regions.

\begin{tabular}{|l|l|l|}
\hline Area & Count & Reference \\
\hline Malayo-Thai waters & 180 & Soledade and Almeida, 2013 \\
\hline Red Sea & 200 & Soledade and Almeida, 2013 \\
\hline Australia & 500 & Soledade and Almeida, 2013 \\
\hline Irani Coast on the Gulf of Oman & 872 & Burukovsky et al. 2017 \\
\hline Omani Coast, Gulf of Oman & 58 females & Ansari and Maghsoodlou, 2017 \\
\hline Eastern Harbour of Alexandria & 76 & Present study \\
\hline
\end{tabular}

On the other hand, the individuals of A. lobidens in the Eastern Harbour are shorter than in some areas of the Pacific Ocean, South African coast, and Iranian Coast on the Gulf of Oman. However, these individuals had close length to those in the western Pacific and Indian Ocean, but they are longer than individuals collected from Thailand, Red Sea, Kaneohe Bay, and Hawaii (Table 3).

Table 3: Maximum total length of Alpheus lobidens in different coastal regions.

\begin{tabular}{|l|l|l|}
\hline Area & TL $(\mathrm{mm})$ & Reference \\
\hline Hawaiian area, Pacific Ocean & 44 & Banner \& Banner 1982 \\
\hline South African coast & 55 & Barnard, 1950 \\
\hline Iranian Coast & 59 & Burukovsky et al. 2017 \\
\hline western Pacific and Indian Ocean & 36 & Soledade and Almeida, 2013 \\
\hline Thailand and Red Sea & 20 & Soledade and Almeida, 2013 \\
\hline Kaneohe Bay, Hawaii & 24 & Banner and Banner, 1974 \\
\hline Eastern Harbour of Alexandria & 32 & Present study \\
\hline
\end{tabular}

According to the regional differences in its length, two populations of $A$. lobidens were distinguished, one with higher growth from the central Pacific (Banner, 1959) and the other with lower growth (up to $36 \mathrm{~mm}$ ) from Malayo-Thai waters, Australia, and the Red Sea (Banner and Banner, 1974). This means that specimens of A. lobidens in the Eastern Harbour could be referred to the population of lower growth. Banner and Banner (1974) supposed that a slight difference in gene pools of the two populations permits the western form to reach greater size. Remarkable colour variations were observed among different specimens from the Red Sea (Banner and Banner, 1981) and in the Persian Gulf specimens (Naderloo and Türkay, 2012). The specimens of the present study were characterized by greenish-brown, pale longitudinal stripes on abdomen, chela brownish, fingers of larger chela orange apically violet, while in formalin preserved specimens the colour turned orange.

The distribution with time of mature females in the Eastern Harbour indicated that summer was more suitable for reproduction of A. lobidens as they formed $62.5 \%$ of the total number of summer shrimps, against $14 \%$ in spring and $9 \%$ in winter. This agrees with Ansari and Maghsoodlou (2017), who recorded high percentage of ovigerous females $(82.7 \%)$ during summer on Omani Coast. Also, the carapace length of the ovigerous females in our study $(8-12 \mathrm{~mm})$ was close to that $(6-15 \mathrm{~mm})$ recorded by Ansari and Maghsoodlou (2017). The occurrence of highest number of individuals in spring in the Eastern Harbour may indicate that water temperature in spring $\left(18-23^{\circ} \mathrm{C}\right)$ was more suitable for the best growth of Juvenile shrimp, while summer temperature $\left(25-29^{\circ} \mathrm{C}\right)$ seems to be better for egg production and embryo development. Ansari and Maghsoodlou (2017) reported 5 developmental stages among 48 females of A. lobidens in Omani coast, but only 3 stages were recognized during our study among 13 ovigerous females collected from the Eastern Harbour.

It is to be noted that this research did not receive any specific grant from funding agencies in the public, commercial, or not-for-profit sectors. 


\section{REFERENCES}

Abdalla, M.A. (1979) Study of the current and hydrographic structure of the water mass in front of Alexandria coast. M.Sc. Thesis, Fac. Sci., Alex. Univ., 100pp.

Abdel Salam, K.M.; Taylor, P.D. and Dorgham, M.M. (2017) A new species of Calyptotheca (Bryozoa: Cheilostomata) from Alexandria, Egypt, Zootaxa, 4276(4): 582-590.

Abushaala, N.M.; Shaibi, T. and Howaege, H.M. (2014) The abundance and diversity of benthic crustaceans along the coastal zone of Western Libya. Journal of Black Sea/Mediterranean Environment, 20(1): 33- 45.

Akbarian, H.; Sakhaei, N.; Savari, A. and Doustshenas, B. (2014) Composition, Abundance and Seasonality of Caridean shrimp larvae (Crustacea: Decapoda) in the mouth of Bahmanshir and Arvand Rivers (the northern Persian Gulf). " $8^{\text {th }}$ International Crustacean Congress (ICC-8) Frankfurt am Main, August 18-23.

Almeida, A.O.; Terossi. M.; Araújo-Silva, C.L. and Mantelatto, F.L. (2013) Description of Alpheus buckupi spec. nov., a new amphi-Atlantic snapping shrimp (Caridea: $\quad$ Alpheidae), based on morphological and molecular data. Zootaxa, 3652: 437-452.

Anker, A.; Ahyong, S.T.; Noel, P.Y. and Palmer, A.R. (2006) Morphological phylogeny of alpheid shrimps: parallel preadaptation and the origin of a key morphological innovation, the snapping claw. Evolution 60: 2507-2528.

Anker, A.; Hurt, C. and Knowlton, N. (2008) Revision of the Alpheus formosus Gibbes, 1850 complex, with redescription of A. formosus and description of a new species from the tropical western Atlantic (Crustacea: Decapoda: Alpheidae). Zootaxa 1707: 1-22.

Ansari, Z. and Maghsoodlou, A. (2017) Some features of the reproductive biology of the Alpheus lobidens de Haan 1850 (Alpheidae) Shrimp-Shrimp in the North Sea of the Omani Sea. Научный журнал «Известия КГТУ, 44: 11-17.

Awad, H.B. (2004) Status of the Main Marine Pollution and Socio-economic Problems Related to the Success of Underwater Archeological Museum Project in the Eastern Harbor of Alexandria. A UNESCO Participation Programme (2000-2001) Project.

Bakir, K.; Ilkyaz, A.T.; Aydin, C. and Turkmen, G. (2015) The presence of Alpheus lobidensDe Haan, 1849 (Decapoda, Alpheidae) on the Turkish Aegean Sea coast. Crustaceana, 88(6): 651-656.

Banner, A.H. (1959) Contributions to the knowledge of the alpheid shrimp of the Pacific Ocean. Part IV. Various small collections from the central Pacific area, including supplementary notes on alpheids from Hawaii. Pac. Sci. 13(2): 130155.

Banner, A.H. and Banner, D.M. (1974) Contributions to the Knowledge of the AlpheidShrimp of the Pacific Ocean Part XVII. Additional Notes on the Hawaiian Alpheids: New Species, Subspecies, and Some Nomenclatorial Changes. Pacific Science 28(4): 423-437.

Banner, D.M. and Banner, A.H. (1981) Annoted checklist of the Alpheid Shrimp of the Red Sea and Gulf ofAden. Zoologische Verhandelingen, Leiden 190: 1-99.

Banner, D.M. and Banner, A.H. (1982) The alpheid shrimp of Australia Part III: The remaining alpheids, principally the genus Alpheus, and the family Ogyrididae. Records of the Australian Museum 34(1): 1-357.

Barnard, K.H. (1950) Descriptive catalogue of South African decapod Crustacea (crabs and shrimps). Annals of the South African Museum 38: 1-837. 
Beckman, C.W. (1948) The length-weight relationship, factor for conversions between standard and total lengths, and coefficients of condition for seven Michagian fishes. Trans. Am. Soc., 75: 237-256.

Ben Amor, K.; Rifi, M.; Ghanem, R.; Draief, I.; Zaouali, J. and Ben Souissi, J. (2016) Update of alien fauna and new records from Tunisian marine waters. Mediterranean Marine Sciences 17(1): 124-143.

Burukovsky, R.N.; Ansari, Z. and Maghsoodlou, A. (2017) Morphology of shrimp Alpheus lobidens de haan 1849 from the littoral of the omani sea (Iran). Научный журнал «Известия КГТУ, 45:72-82.

El Bessa, M.A. (2011) Investigation of waves, current and sea level along Alexandria coastal water. M.Sc. Thesis, Arab Academy for Science, Technology and Marine transport, College of Maritime, transport and Technology $116 \mathrm{pp}$.

El-Geziry, T.M. and Maiyza, I.A. (2006) The hydrographic structure of Alexandria Eastern Harbour. Egypt. J. Aquatic Research, (Special issue) 32: 60-73.

Farrow, G.E. (1971) Back-reef and lagoonal environments of Aldabra Atoll distinguished by their crustacean burrows. In: Regional variations in Indian Ocean coral reefs. Symposia of the Zoological Society of London 28: 455-500.

Forest, J. and Guinot, D. (1958) Sur une collection de Crustacés Décapodes des côtes d'Israel. Bulletin of the Sea Fisheries Research Station, Haifa 15: 4-16.

Galil, B.S. (2007) Seeing Red: Alien species along the Mediterranean coast of Israel. Aquatic Invasions 2(4): 281-312.

Hile, R. (1936) Age and growth of the Cisco Leucichthys artedi (Le Sueur), in the lakes of the north-eastern highlands, Wisconsin. Bull. U.S. Bur. Fish. 48(19): 211-317.

Holthuis, L. and Gottlieb, E. (1958) An annotated list of the decapod crustacea of the Mediterranean coast of Israel, with an appendix listing the decapoda of the eastern Mediterranean. Bulletin of the Research Council of Israel, 7B: 1-126.

Hosseini, S.H. (2009) The intertidal Decapods of Bushehr, northern part of the Persian Gulf. Iranian Journal of Fisheries Sciences 8(1): 37-46.

Jahanpanah, M. and Savari, A. (2013) Investigation of Species Diversity and Dominant of Decapoda in the Intertidal Zone of Bushehr Rocky Shores .International Journal of Environmental Research 7(3): 785-794.

Kocatas, A.; Katagan, T. and Suat Ates, A. (2002) Lessepsian invasion decapod crustaceans at Turkish Seas. Workshop on Lessepsian Migration, 20 -21 July 2002, Gökçeada - Turkey.

Komai, T. (2015) A new species of the snapping shrimp genus Alpheus(Crustacea: Decapoda: Caridea: Alpheidae) from Japan, associated with the innkeeper worm Ikedosoma elegans (Annelida: Echiura: Echiuridae). Zootaxa, 4058 (1): 101-11. doi: 10.11646/zootaxa.4058.1.5.

Lewinsohn, C. and Galil, B.S. (1982) Notes on species of Alpheus (Crustacea Decapoda) from the Mediterranean coast of Israel. Quaderni del Laboratorio di Tecnologia della Pesca, Ancona 3(2-5): 207-210.

Naderloo, R. and Türkay, M. (2012) Decapod crustaceans of the littoral and shallow sublittoral Iranian coast of the Persian Gulf: Faunistics, Biodiversity and Zoogeography. Zootaxa 3374: 1-67.

Naderloo, R.; Ebrahimnezhad, S.; and Sari, A. (2015) Annotated checklist of the apod crustaceans of the Gulf of Oman, northwestern Indian Ocean. Zootaxa 4028 (3): 397-412.

Purohit, B.; Saini, D.; Soni, G.M.; Trivedi, J.N. and Vachhrajani, K.D. (2014) First record of two species of snapping shrimp of genus Alpheus from Gujarat. 
Marine Biological association of India. 163-164, Marine Ecosystem: Challenges and opportunities 2-5 Dec. 2014, Kochi.

Rodríguez, G. and Suárez, H. (2001) Anthropogenic dispersal of decapod crustaceans in aquatic environments. Interciencia 26(7): 282-288.

Soledade, G.O. and Almeida, A.O. (2013) Snapping shrimps of the genus Alpheus Fabricius, 1798 from Brazil (Caridea: Alpheidae): updated checklist and key for identification. Nauplius 21(1): 89-122.

Tan, M.H.; Gan, H.M.; Lee, Y.P.; Poore, G.C.B. and Austin, C.M. (2017) Digging deeper: new gene order rearrangements and distinct patterns of codons usage in mitochondrial genomes among shrimps from the Axiidea, Gebiidea and Caridea (Crustacea: Decapoda). Peer J. DOI 10.7717/peerj.2982.

Zenetos, A. (2017) Progress in Mediterranean bioinvasions two years after the Suez Canal enlargement. Acta Adriatica 58(2): 347-358. 